\title{
PCR based detection of phytoplasma association in pot marigold (Calendula officinalis L.) and guldawari (Dendranthema grandiflora L.)
}

\author{
ANCHAL RANI ${ }^{1}$, PRAGATI MISRA ${ }^{1}$, JITENDRA SINGH ${ }^{2}$, PANKAJ KUMAR ${ }^{2}$, ROSY RANI ${ }^{1}$ AND \\ PRADEEP SHUKLA ${ }^{1}$
}

\author{
${ }^{1}$ Sam Higginbottom Institute of Agriculture, Technology and Sciences, ALLAHABAD (U.P.) INDIA \\ Email : pragati.misra@shiats.edu.in \\ ${ }^{2}$ College of Biotechnology, Sardar Vallabhbhai Patel University of Agriculture and Technology, MEERUT (U.P.) \\ INDIA
}

Flowering plants Calendula officinalis with phyllody and virescence and Dendranthema grandiflora with little leaf and formation of bladder like silique symptoms observed in Uttar Pradesh, India. The presence of phytoplasmas in diseased plants was detected by direct and nested polymerase chain reaction assays using phytoplasma-specific primer pairs P1/P7 and R16F2n/R2. In both flowering plants presence of phytoplasma was confirmed by amplification of $1200 \mathrm{bp}$ product of phytoplasma 16S rRNA region with nested primer R16F2n/R2. This is the first report of phytoplasma associated with Calendula officinalis from India.

Key words : Phytoplasma, Virescence, Phyllody, Nested PCR

How to cite this paper : Rani, Anchal, Misra, Pragati, Singh, Jitendra, Kumar, Pankaj, Rani, Rosy and Shukla, Pradeep (2014). PCR based detection of phytoplasma association in pot marigold (Calendula officinalis L.) and guldawari (Dendranthema grandiflora L.). Asian J. Bio. Sci., 9 (2) : 238-241. 